\title{
Governance of Tuna Industries: The Key to Economic Viability and Sustainability in the Western and Central Pacific Ocean
}

\author{
Kate BARCLAY \\ Institute for International Studies \\ University of Technology Sydney \\ PO Box 123 \\ Broadway NSW 2007 \\ Australia \\ T: +61295141579 \\ F: +61 295141578 \\ kate.barclay@uts.edu.au \\ Ian CARTWRIGHT \\ Thalassa Consulting \\ 13 Monaco Place \\ Howrah \\ Tasmania 7018 \\ Australia \\ T: +6136247 7183 \\ F: +6136247 7183 \\ thalassa@bigpond.com
}

\section{Abbreviated article title}

Governance of tuna industries in the WCPO

\section{Acknowledgements}

This paper is drawn from research conducted for the report 'Capturing Wealth From Tuna' produced as part of an Australian Government Agency for International Development (AusAID) funded postdoctoral fellowship at the Asia Pacific School of Economics and Government at the Australian National University. Support was also provided by the Australian Government Department of Agriculture Fisheries and Forestry. Further writing from the research, including this paper, has been supported by the Institute for International Studies at the University of Technology Sydney. Thanks to Les Clark, Elaine Jeffreys, Justin Liang, Antony Lewis, Robert Gillett, Thomas Gloerfelt-Tarp and Hannah Parris for their helpful input to earlier versions of this paper.

\section{Keywords}

Tuna fisheries, Pacific Island Countries, governance, fisheries management 


\section{Abstract}

The Western and Central Pacific Ocean (WCPO) tuna fishery is an important global food resource, and the economies of many Pacific Islands Countries (PICs) rely heavily on tuna industries. This paper proposes that governance by PICs is the key to improving the sustainability and profitability of tuna industries in the region. 'Governance' is usually used to refer to corruption, but here is interpreted more broadly to encompass the whole process by which decisions regarding public life are made and enacted, by government and also civil society. Argument is supported by empirical material from an interview study with stakeholders and a survey of reports. 


\section{Introduction}

The Western and Central Pacific Ocean (WCPO) is home to the largest tuna fishery in the world. In 200451 per cent of the world's tuna catch was from the WCPO (SPC 2004). Messages of gradually increasing concern have been delivered by the Oceanic Fisheries Program of the Secretariat of the Pacific Community (SPC) over the last decade regarding bigeye, and latterly yellowfin. Stock assessment from the Western and Central Pacific Fisheries Commission (WCPFC) First Regular Scientific Committee Meeting held in August 2005 shows these species are being overfished, although the degree to which this is happening varies regionally across the WCPO (WCPFC 2005). Despite these messages, fishing activity has been allowed to increase substantially (Greenpeace c.2005). ${ }^{1}$ The response of the second WCPFC meeting in December 2005 to the WCPFC Scientific Committee's 2005 recommendations (WCPFC 2005) is considered by some not be sufficiently precautionary because: i) it allows purse seine and longline effort to remain at levels which will continue to allow overfishing; ii) the use of Fish Aggregating Devices (FADs) in the purse seine fishery has not been limited as far as some hoped; iii) the cap set under the Vessel Days Scheme (VDS) is inadequate to address concern over key bigeye and yellowfin stocks; and iv) Pacific Islands Countries’ (PICs) domestic industries have effectively been exempted from most management measures. The effects of the various tuna fisheries in the WCPO need to be carefully analysed and appropriate, effective biological and economic management measures implemented in order to preserve and improve sustainability and optimise economic benefits.

\footnotetext{
${ }^{1}$ There are some limits on purse seine fishing effort imposed through the Palau Arrangement between the countries hosting the bulk of purse seine fishing (Parties to the Nauru Agreement [PNA], the Federated States of Micronesia, Kiribati, Marshall Islands, Nauru, Palau, Papua New Guinea, Solomon Islands and Tuvalu) and its replacement, the much anticipated Vessel Days Scheme, but these are of themselves insufficient to halt the current trend towards overfishing and stock decline. For further information on the establishment of the Palau Arrangement and the PNA see Aqorau and Bergin (1997).
} 
Sustaining and maximising income from WCPO tuna fisheries are particularly important because they are economically crucial to most PICs. Apart from domestic industries and food security issues, access fees paid by distant water fishing countries constitute an important source of revenue for many PICs. Access fees make up as much as 40-50 per cent of Kiribati's revenue, and 22 per cent of the gross domestic product (Government of Kiribati 2003). PICs need fisheries management regimes that maximise economic efficiency while maintaining ecosystems, as does everyone else enjoying food supplies and ecosystem benefits from the Pacific Ocean.

Regional organizations (such as the WCPFC, the Pacific Islands Forum Fisheries Agency [FFA] and the SPC), fishing companies, fishing states, aid donors, and non-government organizations all have important roles to play in improving the economic and biological performance of the region’s tuna fisheries. None of these groups alone, however, can institute the measures necessary to make these improvements. Starting from the basic fact that only PIC governments can legislate for and enforce fisheries management in their jurisdictions, PIC governments, particularly if they act cooperatively, potentially have more power than any of the other stakeholders to improve fisheries management. For example, the majority of the purse seine fishery in the WCPO (around 65 per cent) is carried out in the exclusive economic zones (EEZs) of FFA countries (see Figure 1). Access to these waters is thus essential for the economic operation of the purse seine fleet, so on paper at least the FFA group of countries have control over the purse seine fishery. ${ }^{2}$ The question is whether PIC governments, both individually and collectively, have the capacity and the will to use this power to drive fisheries management improvements. Thus far PIC governments have not shown an inclination to use this power to lead a strong push for improvements in WCPO tuna fisheries. Exercising this power is not easy, since the costs and benefits

\footnotetext{
${ }^{2}$ The longline fishery is more difficult to control, given that the reverse situation prevails, with most fish taken on the high seas.
} 
of restraint, particularly in the purse seine sector are unevenly distributed, both between distant water fishing interests and within the FFA group. We propose that conceiving of fisheries management as a broad governance issue helps bring into focus some of the factors affecting PIC governments’ performance in this sector.

This paper is based on research conducted in 2005 consisting of interviews with stakeholders and a survey of reports on tuna fisheries in the WCPO across a representative selection of six independent PICs—Papua New Guinea, Solomon Islands, Marshall Islands, Kiribati, Cook Islands, and Fiji. While regional cooperation is also vital for fisheries management in the WCPO, this paper focuses on the role of governments in their domestic sphere in influencing profitability and sustainability of tuna industries. Background information about the WCPO fishery is presented and the concept of governance discussed, then effects of reforms that have been carried out in these PICs are outlined. The main part of the paper discusses access fees, social and political factors in fisheries, and the extent to which consultative processes are used in fisheries in PICs. The examples used demonstrate that improved governance is a vital first step to improving profitability and sustainability in WCPO tuna fisheries.

\section{Background}

\subsection{Governance of Fisheries}

Governance refers to the process whereby elements in society wield power and authority, and influence and enact policies and decisions concerning public life, and economic and social development. Governance is a broader notion than government, whose principal elements include the constitution, legislature, executive and judiciary. Governance involves interaction between these formal institutions and those of civil society (The Governance Working Group of the International Institute of Administrative Sciences as quoted in GDRC 2006).

Fisheries management may be characterized as part of the governance of fisheries. An ideal of fisheries governance might involve government working with industry and other stakeholders to manage fisheries such that they are sustainable and 
profitable. Aid donors have been concerned with governance as a central development issue for several years now, but unfortunately a 'good governance' agenda has been pushed in ways that have implied that donor countries have 'good' governance while aid recipients have corrupt and/or incompetent ‘bad' governance (Johnson 1997). The collapse of Enron in the USA and the more recent scandal of the Australian Wheat Board paying bribes to Saddam Hussein's regime, however, show that problematic governance is as rife in 'the West' as it is anywhere. This paper aims to move beyond the potentially condescending 'good governance' approach to consider the influences of specific governance arrangements on the success of fisheries, and suggest changes that may promote or impede sustainability and profitability. In this approach governance is analysed not as something 'good' or 'bad' but as something that frames economic environments in particular ways_-facilitating (or otherwise) sustainable and profitable business development.

\subsection{The Fishery}

The WCPO oceanic tuna fishery is based on four key species—skipjack, yellowfin, bigeye and albacore tuna. The tropical tuna species are more productive than the more temperate tunas, including the heavily overfished Pacific bluefin and southern bluefin tunas. The most productive area for tuna lies in the equatorial zone $\left(10^{\circ} \mathrm{N}-10^{\circ} \mathrm{S}\right)$ where around 80 per cent of all tuna from the WCPO are caught. Skipjack and small yellowfin and bigeye tuna school (frequently together) on the ocean surface and are commonly found in the tropical and subtropical waters of the WCPO. Larger yellowfin and bigeye are generally found in deeper water, where they are more widespread, although some larger yellowfin are also caught in free-swimming schools. In contrast to skipjack and yellowfin tuna, albacore concentrate in temperate areas where food is abundant. 
There are three main types of tuna fishing conducted in the WCPO; purse seine, longline and pole-and-line (SPC 2005). The provisional 2004 purse seine catch of around 1,200,000 metric tons was the highest on record and the catch has been around this high level for the past three years (Williams and Reid 2004). Purse seine vessels primarily target surface-swimming skipjack, with associated catches of small yellowfin and bigeye. The operation is highly technology- and capital-intensive, with new vessels costing in excess of USD\$25 million. Distant water fishing fleets from Korea, Taiwan, Japan, and the United States of America (USA) account for around 75 per cent of the purse seine catch, with vessels based in PICs fishing under the Federated States of Micronesia (FSM) Arrangement and Philippines vessels catching the balance (Williams and Reid 2004). ${ }^{3}$ The fishery is a high volume, relatively low value (per tonne) fishery. In recent times many fleets have suffered from a profitability squeeze with increasing fuel and other costs and global oversupply intermittently depressing prices. While prices have trended upwards in recent times, and the catches per unit of fishing effort (CPUE a measure of efficiency) have increased substantially for some fleets, the fact that fuel price has increased by around 300\% since 2002 (Krampe 2006) has tended to offset these gains. The Taiwanese fleet, however, has expanded substantially in recent years, and may be considered as an indication of i) relatively profitable operation (due both to low costs and increases in efficiency and ii) confidence in the future. It would be useful to understand more about the cost-price structure of this and other fleets, including any possible hidden subsides that may apply. Conversely, the USA fleet has been particularly hard hit and the numbers of vessels operating in the WCPO have reduced from around 50 when the USA multilateral access treaty was first signed in the 1980 s to less than 20 vessels in 2005.

\footnotetext{
${ }^{3}$ The FSM (Federated States of Micronesia) Arrangement is a reciprocal access agreement between members of the PNA Group countries that gives priority to local and locally based vessels.
} 
The longline fishery accounts for around 10-12 per cent of the total WCPO catch (around 220,000mt in 2004) but is about the same value as the larger purse seine catch, reflecting its uses for premium sashimi and other higher (than canning) value products (Williams and Reid 2004). This method targets fewer, larger, deeperswimming tuna using hooks set over a minimum of tens of kilometers of ocean. Longline vessels in the WCPO are of two main types; large, distant water freezer vessels (which tend to be based in distant water fishing countries) and smaller offshore vessels specializing in chilled fish (which tend to be based in PICs). In recent years domestic longline fishing has suffered from periods of falling or stagnant prices in the major markets and rising fuel and airfreight costs. As with the purse seine fleet, the profitability and hence attractiveness for investment between longline fleets varies widely. The low-cost Chinese and Taiwanese fleets continue to expand at a greater rate than the declining Japanese and Korean fleets, with Taiwan increasing its distant water longline fleet from 78-137 vessels between 2000 and 2004 (SPC 2005).

Catches by pole-and-line vessels in the WCPO has been around 270-300,000 metric tons in recent years. More than 90 per cent is taken by Indonesian and Japanese fleets. Since pole-and-line fisheries target the same species (skipjack) as purse seiners, the overall efficiency of purse seining has resulted in a marked decline in the number of pole-and-line vessels in the WCPO. This is unfortunate, since the pole-and-line method is the least ecologically damaging and most labour intensive of the three main tuna fishing methods used in the WCPO. The medium scale shore-based pole-and-line fisheries that have been based in PICs are much higher cost per tonnage of fish than the purse seine method. Inability to compete on price with purse seine product means poleand-line fisheries formerly operating in Palau, Papua New Guinea (PNG) and Kiribati are no longer active, only one vessel is now operating (seasonally) in Fiji, and the small 
fleet operating in Solomon Islands is suffering financial viability problems (Barclay 2005).

There are thus problems with sustainability and/or profitability in all of these three fisheries. Profitability is the main problem for the pole-and-line fishery, while domestic longline fleets are suffering from both profitability and sustainability problems. Purse seining itself is not yet experiencing problems with catch per unit of effort (CPUE), but 2005 WCPFC Scientific Committee data indicates that purse seine activities are contributing to sustainability problems in the longline fishery. An interesting point about the WCPO tuna fishery is that profitability and sustainability components are in different relationships to each other in different sectors. Most notably, yellowfin and bigeye stock depletion make the southern longline fishery unprofitable long before biologically significant impacts on those stocks as a whole occur. And the equatorial purse seine skipjack fishery may remain profitable even after the overall yellowfin and bigeye stocks are driven below biologically sustainable levels. Views on tuna development and the impacts of various management measures, such as a reduction in effort in a given gear type (such as longline or purse seine), thus vary between PICs across the region.

\section{Improving Profitability and Sustainability through \\ Governance}

The ways in which governance can improve profitability in fisheries in the Pacific by improving the business environment have been discussed in many reports (ADB 1997; Petersen 2002; Chapman 2004; Gillett 2003; Barclay and Cartwright 2005). Most PICs suffer from geographic disadvantages in being small economies distant from established trade routes, but PIC governments have contributed to economic problems through policy choices. The Taiwanese fishing company Ting Hong 
was infamous for its short-term gain mentality in the 1990s, but it should be noted that PIC governments have attracted this style of operation by making it very difficult for locally based companies with more long-term visions to be successful. One of the ways PIC governments have discouraged business development in the past was through state ownership of tuna enterprises. After decades of failure by state owned enterprises there is now less state ownership, but other problems persist, such as lack of coordination between government departments and policy instability (Bowman 2005), inconsistent tax regimes (Hand 1999) and systems of land tenure that are not amenable to capitalist development. Tuna industries rely on a range of government services including fisheries licensing, foreign investment and working visa approvals, food safety administration for export destinations, and administration of land tenure, but these services are not always timely, accessible, effective, consistent or reasonably priced.

Over the last decade changes to fisheries governance in terms of departmental reform and restructuring in PNG, Marshall Islands, Fiji and Cook Islands have led to improved business environments and therefore greater private sector development. For example, purely through governance reforms Cook Islands went from having no tuna industry to speak of to having tuna exports rival pearl exports, adding depth and diversity to an economy in which pearls and tourism were virtually the only private sector opportunities. Other PICs that have been unable or unwilling to reform fisheries management, such as Solomon Islands and Kiribati, have had stagnant private sector development (Barclay and Cartwright 2005).

In the late 1990s PNG embarked on a restructuring of the fisheries department, which had focussed mainly on small scale rural fisheries extension services. A statutory authority the National Fisheries Authority (NFA) was created to service industry and collect fees on behalf of government. PNG's experiences offer many useful lessons about the effects of governance on fisheries development. As a statutory authority that 
raised its own revenue the NFA was able to pay its staff more and provide better equipment and facilities, which tended to improve performance. One measure of this improvement is that the amount of access fees negotiated from distant water fleets by NFA jumped from an estimated USD\$5.8 million in 1999 (Gillett and Lightfoot 2002) to over USD\$9 million in 2002 (Lewis 2005), to USD\$13.6 million in $2003 .^{4}$

Fisheries policy was also changed during this time, to facilitate the development of locally based industries. There had been no long lining in PNG since the 1980s. After the reforms, from 1995 around 40 locally owned longline vessels operated from several different locations around the country. Policies were also changed to entice distant water purse seine companies to set up processing factories on shore, starting with RD in Madang in 1997, followed by South Seas Tuna in Wewak in 2004 and Frabelle in Lae in 2006. Improved administration and the new policies thus contributed to a boom in domestic development. The value of PNG's tuna exports went from around PGK3.5 million in 1996 to over PGK220 million in 2002 (Gomez 2005).

These positive improvements to revenues raised through fisheries and the extent of domestic fisheries economic activity, however, do not mean that PNG fisheries governance reforms have been an unqualified success. For example, the economic soundness of coercing/enticing domestic investment through fisheries access is questionable; if such investment were economically viable coercing/enticing should not be necessary. One report estimates that the level of tax relief given to RD means lost revenue cancels out the development gains of having the large processing factory employing 3,000 people in Madang (Gillett Preston and Associates 2000c). PNG's endemic corruption (Pitts 2002) also negated some of the gains achieved in the reforms, in that apparently not all the revenue from access fees actually made its way to government coffers (Lewis 2005).

\footnotetext{
${ }^{4}$ Preston, Garry. 2005. Fisheries management consultant, Gillett Preston and Associates. Personal communication (email) 17 December.
} 
PNG's governance reforms have also yet to demonstrate improvements in thus sustainability of tuna fisheries. As the major tuna fishing ground in the equatorial Pacific, PNG is the key to fisheries management for the region, but has not made any substantial changes to policy in response to the alarming figures presented at the WCPFC in 2005 (WCPFC 2005). This is despite the fact that falling catch rates for the most valuable types of fish apparently caused by equatorial purse seining is one of the factors that has caused the collapse of most of PNG's domestic longline companies after 2002.

Governance has failed to protect the profitability of the PNG longline industry in various ways. For example, PNG’s national carrier Air Niugini enjoys monopoly status. Air Niugini did not effectively have the capacity or the route connections to be suitable for chilled fresh tuna exports, and its prices were uncompetitive, so PNG longline fishing companies tried to organize charter flights from an airfreight company. Air Niugini, however, lobbied to prevent departmental approvals for regular use of the airfreight company and prevented any tuna shipments not using Air Niugini from using the cold store facilities for tuna at Port Moresby airport (The National 2005). In 2005 the company Heavylift finally secured permission to run regular tuna freight flights from Port Moresby (without access to the cold store) but by that time all of the longline fisheries outside Port Moresby had closed down, in part due to the high price and logistical difficulties of Air Niugini’s services (Tai 2004).

While PNG's governance reforms facilitated a boom in domestic tuna business development, therefore, PNG's governance has still impeded profitability, and has failed to seriously tackle sustainability issues. 


\subsection{Governance of Distant Water Fishing Access}

Many commentators have remarked on how little of the gross value of the WCPO tuna fishery (five to six per cent) is returned to PICs through access fees paid by distant water fishing countries (for example, Petersen 2002). Access fees, however, have to come from profits and it is arguable that with current economic circumstances facing the fishery higher percentage fees might not be feasible. The multilateral treaty with the United States fleet currently pays more than twenty per cent of the landed vale of the steadily decreasing catch by that fleet (and was around eleven per cent even at the time of negotiation) but agreements based solely on commercial considerations (rather than strategic or political considerations) seem unlikely to achieve more than eight per cent of the landed value of the catch. This is considered to be the ceiling in most tuna fisheries, with even six per cent seen as a burdensome 'royalty payment' (Lewis 2005). Nevertheless, there are ways PICs can increase the revenue raised through access license fees through improved governance of access agreements.

Some form of 'gift' to coastal state negotiators was widely assumed by interviewees to be part of distant water access negotiations. It was felt that such gifts were probably a negative influence on the outcome for PICs, because they carry an expectation that the recipients of gifts would not push so hard for higher fees or strict fisheries management. Dealing with corruption in access fee negotiations may have an immediate positive effect on the amounts of revenue generated. In Solomon Islands the fisheries department was audited in 2003 and several millions of (US) dollars were found to be missing (Islands Business 2004). Since 2003 the Solomon Islands government has taken steps to make fisheries officials accountable for apparent corruption with license fees, and has undertaken a government-wide initiative to improve administrative systems; with budgets tied to documented planning, budget estimates, and annual reporting of achievements and expenditure. Solomon Islands' 
access fees jumped from an estimated USD\$1.9 million in 1998 to USD\$3.9 in 2004 (Barclay and Cartwright 2005). As in PNG improvements were due to the fact that fees were making their way to government bank accounts instead of personal ones, and also due to improved negotiations based on realistic fees.

Governance of access agreements is not just about corruption and anticorruption, however. Effective administration of access agreements is also crucial. Capacity is a large factor in effective administration. Small government departments find it difficult enough to develop the necessary human resources in fisheries biology, let alone the financial expertise needed to work out the best basis for calculating fees, and to independently check market figures to make sure fishers are paying the appropriate amounts. Yet without this financial expertise governments cannot be sure they are being paid all they should be under access agreements (McCoy and Gillett 2005; van Santen and Muller 2000; FFA 2001).

In the past, FFA provided staff to sit in on bilateral access negotiations as technical advisers to PICs but this practice ceased in the early 1990 s. ${ }^{5}$ For some, the presence of an adviser (usually not a Pacific Islander) was seen as patronizing, and unnecessary once capacity was developed in PICs. Others, however, are of the view that such assistance would prevent the use of spurious data and prices by distant water fishing countries and increase transparency in light of 'gifts' and other corrupt practices.

As well as improving integrity and effectiveness in administration of access agreements, another way PICs may increase the revenue from access fees is to rethink the way access agreements are negotiated. One of the most commonly raised strategies to improve PICs' return from distant water fleets is that they should negotiate collectively with distant water fishing countries rather than on a bilateral basis. Thus far the only multilateral agreement is with the USA fleet. Reasons PICs have not

\footnotetext{
${ }^{5}$ Although FFA continued to provide, on demand, a range of market intelligence and other information to assist in access negotiations for member countries.
} 
cooperated for multilateral agreements with other fishing countries include: reluctance among PIC officials to 'surrender sovereignty' or to lose the capacity to negotiate ‘tailor-made’ agreements suited to their particular countries; the fear that bilateral aid from fishing countries might be cut if PICs join a multilateral push to negotiate fees; and unwillingness to forgo personal 'perks' from bilateral negotiations on the part of PIC fisheries officials.

In addition to multilateral negotiations, there are other ways PICs could rethink their approach to distant water fisheries access. A recent ADB report (ADB 2005) argues that PICs’ past and current practice of maximising access fees though high levels of fishing, without due regard for fisheries management, has resulted in a race-to-fish that is likely to reduce the overall economic benefit available from the fishery, and thus limit the amount fishing companies can pay in fees (see Figures 2 and 3). If PICs were to stop treating access fee negotiations as a revenue issue separate to fisheries management, and instead consider the long-term generation of revenue as part of fisheries management, WCPO tuna fisheries would arguably be both more sustainable and profitable. If effective fisheries management is able to prevent overfishing and the inevitable associated catch and revenue declines, DWFNs may be willing to maintain or increase payments to PICs for fishing opportunities. Profitable DWFNs can also improve the potential for profitability in domestic tuna fisheries.

Early bio-economic modelling work by FFA and SPC suggested that reductions in purse seine effort could yield substantial overall increases in economic benefits, principally by reducing catches, increasing CPUE and price (by restricting supply) and reducing the costs of fishing. Some of these findings led to assertions that the key to PICs increasing economic benefit from the purse seine fishery was to restrict effort (see for example, ADB 2003). More recent bio-economic modelling work (Reid Bertignac and Hampton 2006) has questioned this perspective, noting that as skipjack catches 
have increased, CPUE has been maintained, or in some cases increased. Revenue streams from access fees have increased by ten per cent in the period 1999-2003 (Lewis 2004). Using an updated bio-economic model the economic benefits (rent) of reducing effort in the purse seine fishery, while present, are forecast to be substantially less, although the effect on reduced supply in terms of increased prices could increase that benefit.

In any event, while the more recent work demonstrates that earlier arguments about reducing purse seine effort for sustainability and profitability were too simplistic, the fact remains that bigeye and yellowfin stock depletion remains a problem for both the purse seine and longline fisheries, and that successful management is the key to both sustainability and profitability. An example of a strategy following this logic would be if the PNA group of countries (which have the power to control purse seine fishing in the region) were to: i) use a sub-regional arrangement to fully 'pool' fisheries access to their combined EEZs; ii) put in place credible measures to prevent overfishing; and iii) use rights-based management approaches to sell long-term rights (as long as ten years), thereby giving fishing companies maximum confidence in their investment. ${ }^{6}$

PICs have never tried most of the ideas that have been proposed about rethinking the way access fees are negotiated in order to increase access fees. One reason PICs have not explored new ways of conducting access arrangements is that most of these strategies have been proposed in reports by consultants submitted to the FFA Secretariat. The strategies have not been workshopped with PIC officials in consultative forums. Another reason is that small government departments trying to get by on very limited resources simply do not have the human resources (in terms of numbers or range of expertise) to try new ways of organizing negotiations. Access fees are thus an area where improved governance in the areas of corruption, effectiveness of

\footnotetext{
${ }^{6}$ Thomas Gloerfelt-Tarp, Senior Natural Resources Specialist, Pacific Operations Division, Asian Development Bank, interview, 28 September 2005. Suva, Fiji.
} 
administration and policy strategy could clearly improve profitability and sustainability, but where human resources significantly restrict the capacity to improve governance.

\subsection{Social and Political Factors and Consultation in Fisheries Governance}

Access fees are a fairly obvious example of how governance may affect profitability and sustainability in fisheries. The rest of this paper considers areas that are less directly connected to profitability and sustainability, but arguably no less important. Politics is usually seen as something that should be kept out of fisheries management. Social issues are more widely recognized as a legitimate part of fisheries management but they are not generally taken as a serious core issue. Since fisheries management is more about managing people's impact on fish rather than about managing fish per se, however, fisheries management should always take social and political factors into consideration. One reason for this is that social and political problems arising from tuna developments may rebound negatively on those developments, exacerbating already difficult business environments.

Development of tuna industries in PICs has usually been perceived as socially destructive. While people have appreciated the employment opportunities offered by such developments, tuna processing factories in Fiji, Solomon Islands, and PNG have had bad public reputations. They have been widely seen as offering unpleasant unsafe work for substandard wages, as causing social breakdown, and as polluting the surrounding environment (Emberson-Bain 1994; Stinus-Remonde 2004; Hughes and Thaanum 1995; Sasabe 1993; Sullivan et al. 2003). Companies have tried to improve their image through community relations programs, but have not managed to effectively address public disquiet. Fisheries managers and other local leaders have often tended to contribute to the rhetoric of corporate misbehaviour (Hughes and Thaanum 1995), 
sometimes apparently in an effort to shore up support for themselves by representing tuna companies as exploitative, neocolonial foreign capital.

Failure to address the negative social reputations of tuna processing companies has meant social groups continue to attack them. PNG-based Philippines-owned tuna fishing and processing company RD has been the target of petty extortion rackets (PostCourier 2005) and has been tied up in legal battles with landowner groups and an NGO that RD perceives as having slandered the company (Friends of Kananam c.2003). The social ill will generated by many tuna developments in the region is thus part of a generally unfavourable business environment.

One of the factors contributing to widespread social ill will against industrial tuna developments in the Pacific is the pervasive belief that commercial tuna industries are depleting the resources villagers catch for food and income. Nearshore fisheries are of paramount importance for food security, health and income of coastal PIC populations (Chapman 2004). It is common to hear from small-scale and recreational fishers in PICs that is it now much harder it is to catch tuna than it was 10 or 15 years ago, and commercial tuna fisheries are usually seen as the main cause of the apparent decline in resources, ${ }^{7}$ although there is little research based evidence either way, and fisheries officers in Solomon Islands feel that increased populations in coastal areas, pollution, over fishing, and unsustainable fishing practices (such as dynamite fishing) are also having a negative impact on the health of coastal fisheries resources. ${ }^{8}$

It is also commonly believed that large-scale tuna processing plants in PNG and Solomon Islands pollute the surrounding environment, and damage reef fish stocks

\footnotetext{
${ }^{7}$ Some of the interviewees who expressed this opinion in 2005 included: Steve Dunn, Deputy Director, Forum Fisheries Agency (FFA), interview, 12 July 2005, Honiara, Solomon Islands; Nauan Bauro, General Manager, Kiribati Fisherman Services Company Limited (KFS), interview 13 October 2005, Bairiki, Tarawa, Kiribati; Keith Kingston, Lae businessman and recreational game fisherman, personal communication, 15 May 2005, Lae, Papua New Guinea; Emmanueal Tamba, Fisheries Extension Officer, New Ireland Provincial Government, interview, 26 May 2005, Kavieng, Papua New Guinea; Peter Ramohia, Research Officer, Fisheries Department, interview, 15 July 2005. Honiara, Solomon Islands. ${ }^{8}$ Government of Solomon Islands. 2005. National Fisheries Workshop, Solomon Islands National and Provincial Fisheries Departments, at King Solomon Hotel, Honiara, Solomon Islands, 25 July - 3 August.
} 
(Barclay 2001; Sullivan et al. 2003). Some research has been conducted into the pollution effects of large-scale canneries Solomon Taiyo and RD (Benet Monico 2003; Mani 1994; Wallis 1999), but PIC governments have not implemented ongoing environmental monitoring or enforcement schemes. Indeed, in the case of Solomon Taiyo, the greatest impetus for environmental monitoring and improving waste disposal was meeting the requirements for European market access, not domestic government regulation (Barclay 2001).

More effective governance of nearshore fisheries would be based on consultation with coastal communities and include monitoring of the effects of industrial tuna fisheries and processing (as well as other influences), and putting effective measures in place to halt any declines in nearshore fisheries resources. Recent government, non-government and aid donor supported establishment of community based coastal resource management in several PICs could evolve in this direction. Thus far, however, these mechanisms still do not monitor or disseminate information about the impacts of commercial tuna enterprises on coastal fisheries.

Another source of public dissatisfaction with tuna industries in the WCPO is the range of social problems including prostitution, substance abuse and violence that arise around international ports and tuna factories (Barclay 2001; Emberson-Bain 1994; Sullivan et al. 2003; Pacific Islands Forum Secretariat 2004). For example, 35,000 men from the southern Philippines work overseas on fishing vessels and call into ports including those in Solomon Islands as well as PNG, Indonesia, Malaysia and Taiwan. According to a health official from General Santos City in Mindanao, many of these fishermen engage in 'extremely risky behaviour' when they finish a trip, including sex with multiple partners (often involving binge drinking and sex workers), injection of recreational drugs, and insertion of penile implants. While the General Santos official knew of no cases of HIV/AIDS reported among the fishermen, it was noted that there 
appeared to be a high rate of tuberculosis among the fishermen, which is recognized to be an indicator of AIDS (Solomon Star 2004). PNG's rates of HIV/AIDS are now very high. Vessels visiting PNG could contract the disease and spread it around the Pacific very quickly.

Another important factor contributing to social dissatisfaction with tuna developments in PICs is that the distribution of benefits from the industries has been seen as inequitable. Pacific Islander interviewees were particularly concerned that benefits from tuna developments should be felt in rural or outer island areas, and the fact that benefits from tuna industries have generally not been realized at the village level (except in the few areas supplying workers) was seen by interviewees as a major failing in PICs' fisheries development policies. This was often expressed in the following terms: 'villagers see the tuna boats fishing off their coast, they feel the tuna boats are taking their resources, yet they get nothing in return' ${ }^{9}$ Strictly legally PIC villagers have no claim in customary tenure to offshore resources, however, the social reality of customary marine tenure in PICs is that villagers sometimes assert rights over resources they did not use in custom (Kinch et al. 2005). Furthermore, anecdotes suggest that industrial fishers often come in much closer to shore than they should, particularly longliners targetting reef sharks. ${ }^{10}$ The belief that commercial tuna fisheries are taking villagers' resources without giving any return to villagers is one of the factors contributing to social ill will towards commercial tuna industries in PICs.

Interviewees often hoped that rural fishers could somehow become involved in commercial tuna fisheries, but the perishable nature of the product makes it difficult for small scale fishers to transport tuna to markets at a viable cost, and small vessels are much less efficient than large industrial vessels. Another way coastal villagers could

\footnotetext{
${ }^{9}$ Aini, John. 2005. Trainer, Ailan Awareness NGO and Data Management Specialist, PNG National Fisheries Authority Coastal Fisheries Management and Development Project (ADB Project). Interview, 26 May. Kavieng, Papua New Guinea.

${ }^{10}$ These vessels often operate illegally, their catches are often in competition with local fishers, and they have the potential to disrupt reef and reef slope ecosystems by removing a top predator.
} 
benefit from commercial tuna industries is if a portion of the commercial fisheries license fees are channelled into trust funds for rural coastal development projects. Most of the Tuna Management and Development Plans in the Pacific include such a policy, but Marshall Islands was the only one of the countries visited for fieldwork in 2005 that had implemented the policy.

The most significant strategy that has been employed by PICs to distribute benefits from tuna industries has been to spread industrial tuna developments away from established industrial or urban centres. In PNG this has led to large-scale tuna processing ventures in Madang, Wewak and Lae, with longline developments spread even more widely. In Solomon Islands there are tuna bases at Tulagi and Noro, with an additional base planned for Bina Harbour in Malaita. In Fiji the Pafco cannery/loining plant is located away from the capital, at Levuka on Ovalau.

The problem with spreading tuna developments out geographically is that having many locations for industrial development exacerbates the diseconomies of scale that already damage the economic viability of PIC developments. Countries such as China have demonstrated the economic success that may be achieved by consolidating industrial development in special economic and export processing zones. Consolidating tuna fishing, service and supply and processing industries geographically could generate business development in clusters of firms with operational synergies, which share a pool of infrastructure and resources (including human) that improve as more companies join the hub (Bowman 2005). For this reason RD has been trying to attract more businesses to Madang for some years. The PNG government, however, seems to want 'a tuna factory in every port', echoing the 'meat cannery in every town' scenario of the late 1980s that saw the establishment, and subsequent collapse, of several competitors to James Barnes Pty Ltd’s monopoly (Bowman 2005). Solomon Islands and Fiji are equally committed to having tuna industries in regional areas for social and political 
reasons. In these cases social and political factors are being considered in fisheries governance, but at the expense of, rather than in balance with, economic imperatives. Better management of the social and political aspects of fisheries development could facilitate a widespread sense of social benefit rather than the social dislocation and polarization of groups for and against that characterizes tuna development in the Pacific. One way to address this cluster of social and political problems affecting profitability (through the business environment) and sustainability (especially in coastal areas) of Pacific tuna industries is to improve consultative processes in fisheries governance.

PICs' fisheries governance has on the whole been marked by a lack of consultation; between government departments, with affected communities, with social and environmental non-government organizations, and between government and industry. PIC officials have tended not to see the potential value of non-government organization (NGO) input, and tended to treat fisheries governance as being a purely government responsibility, rather than engaging in consultative decision making processes with other stakeholders (Cartwright 2004). PIC governments are not used to including NGOs and do not really see NGOs as being legitimate voices in decisionmaking processes. Working with other stakeholders, however, would enable government departments to improve outcomes in terms of profitability and sustainability in tuna industries in various ways, especially in the context of very limited human resources in PIC government departments.

Closer consultation with industry helps government make better informed management and development policies and better administer regulations, especially in terms of setting fees and ensuring compliance. Strong fishing associations that have actively engaged with government departments have been positively correlated with industry development in places like Fiji and PNG, while poor industry-government 
dialogue in places like Solomon Islands has correlated with more difficult business environments (Gillett 2003). Some PIC officials, however, take an adversarial approach to industry NGOs (INGOs) (Gillett 2003), and PIC officials have demonstrated a reluctance to include industry representatives in fisheries negotiations in fora such as the Preparatory Conferences for the establishment of the WCPFC (Cartwright 2004).

There has been even more reluctance on the part of government officials to include environmental NGOs (ENGOs) in governance processes, due to perceptions that such groups are anti-developmental, anti-government, or too 'Western' to be a legitimate part of Pacific Islander governance (Gillett 2003; Cartwright 2004). Environmental organizations, however, can help with governance in several different ways. One is to collaborate in resource management, as several groups are currently doing with coastal marine protected areas and community based coastal resource management around the Pacific. ENGOs and social issues based NGOs may also facilitate consultation with village communities about coastal social and environmental issues. The ENGO Ailan Awareness in New Ireland in PNG has taken on this role.

Environmental groups can also indirectly help with the profitability of fisheries. Constraints relating to environmental issues are becoming increasingly important for tuna industries. These issues may be relatively minor compared to tuna stocks and bycatch management, but they impact on PICs’ ability to sell their products in the sensitive markets of the USA and Europe. A study has found that 79 per cent of European consumers, supermarket buyers, chefs and restaurateurs said that the environmental impact of seafood is an important factor in their purchasing decisions (WWF 2005). In 2004 sales of tuna loins from Solomon Islands to Italy were blocked by European environmentalists campaigning against Solomon Islands allowing live dolphins to be caught and exported for amusement parks. International campaigns to ban long lining because of stock depletion in some tuna species and incidental deaths of 
birds, turtles and sharks damage the public image of tuna as a product, as does pollution from vessels and ship groundings. Some environmental groups can work with governments and industry to improve environmental performance in fisheries, with positive outcomes for both sustainability and profitability.

Greater consultation with civil society groups and other government departments could also improve governance of the social, welfare and health problems that arise around tuna ports and factories. Ideally, a wide range of services would be provided around these centres, including advice about prevention of and treatment for sexually transmitted infections (STIs); services for women who are subject to violence and other problems related to prostitution and substance abuse; and physical and mental health services for crews who are out at sea for months on end, often on cramped vessels. Many Pacific Island ports have an extremely limited range of activities available for visiting fishing crews. While vessels are in port in the Pacific crews may have virtually nothing to do, and crew who do not want to engage in sex or substance abuse have nowhere to escape these activities occurring on board. In other parts of the world crew have the option to stay at 'Seafarer's Angel' houses and get away from their boat for a few days. Interviewees suggested that providing visiting crew with a wider range of social amenities around port areas, such as shops, cinemas and restaurants, would help diffuse crews’ more socially undesirable behaviours (Barclay and Cartwright 2005).

Clearly fisheries departments alone cannot be expected to develop the full range of expertise needed to cover all aspects of fisheries governance by themselves. Consultation and collaboration is the only feasible way to address all of the disparate biological, economic, social and political issues raised in fisheries development and management. As with improving governance of access fees, however, the capacity to consult and collaborate is constrained by resources. Small government departments find it difficult enough to cover a narrow range of fisheries functions and would require 
more staff to be able to work with other government departments and NGOs on health and social welfare issues related to tuna industries. For ENGOs to participate effectively in the regional fisheries management negotiations ongoing within the WCPFC a great deal of international travel is required, and many local NGOs simply cannot fund their employees to do this travel (Cartwright 2004). Even INGOs find it difficult to justify the time and money to participate effectively in governance processes, which are run by bureaucrats and include lengthly committee meetings (Cartwright 2004). Interviewees noted in 2005 that this was the main reason that the regional fishing industry association established in 2004 had thus far not really worked as planned.

Nevertheless, the value of consultative processes seems to be more widely recognized by PIC officials than it was in the past, and the extent of consultation in PIC fisheries governance seems to be increasing. In July-August 2005, the Solomon Islands government held a national workshop to set government's strategic plan for fisheries, which included significant ENGO participation. And in late 2005 the Fijian government was working closely with industry groups to improve fisheries license conditions for 2006.

\section{Conclusion}

Since the PICs extended control over fishing grounds to 200 nautical miles out from their coastlines in the 1970s they have achieved a great deal in terms of fisheries governance in some areas. They have established excellent scientific data collection for stock assessment, collaborated for maritime surveillance, and developed regional and international organizations (SPC, FFA and the WCPFC) to assist with fisheries management and development advice. But not much headway has been made in furthering the core fisheries management goals of promoting maximum economic benefit and sustainability. Seeing the will and capacity of PIC governments to promote 
profitability and sustainability as a governance issue helps explain this state of affairs and suggest strategies for improving the situation.

Anti-corruption is only one small part of what we mean by 'governance'; the main thrust of the argument is that governance of fisheries management and development should be conceived of broadly to include a range of biological, economic, social and political issues. The limited resources within PIC governments and in civil society constrain the extent to which fisheries governance can be addressed in this way, but the examples presented in this paper show that significant achievements may occur through adjusting mindsets and ways of doing things, some of which may not require great funding increases. When PICs are better able to promote economically efficient outcomes and sustainability in their domestic spheres through improved governance, they should also have greater will and capacity to achieve profitable and sustainable fisheries for the region. 


\section{References}

ADB. 1997. The Pacific's Tuna: The Challenge of Investing in Growth, Pacific Studies Series. Manila: Asian Development Bank (ADB).

— 2005. On or Beyond the Horizon: A Discussion Paper on Options for Improving Economic Outcomes from the Western and Central Pacific Tuna Fishery (ADB TA 6128-REG 226). Manila: Asian Development Bank (ADB). Aqorau, Transform, and Anthony Bergin. 1997. Ocean Governance in the Western Pacific Purse Seine Fishery - the Palau Arrangement. Marine Policy 21 (2):173186.

Barclay, Kate. 2001. Foreign Bodies in Tinned Tuna: Modernism, Identity Relations and Economic Practice in a Japanese Joint Venture in the Solomon Islands, PhD thesis, Humanities and Social Sciences, University of Technology Sydney, Sydney.

—. 2005. Tuna Dreams Revisited: Economic Development Contributions from a Tuna Fishing and Processing Enterprise in Solomon Islands. Pacific Economic Bulletin 20 (3):78-93.

Barclay, Kate, and Ian Cartwright. 2005. Capturing Wealth from Tuna: Key Issues for Pacific Island Countries (discussion draft). Canberra: Asia Pacific School of Economics and Government, Australian National University.

Benet Monico, Ariadna. 2003. Madang Lagoon Water Quality Monitoring. Madang, Papua New Guinea: World Wild Fund for Nature (WWF) South Pacific Programme.

Bowman, Chakriya. 2005. Business Development in Papua New Guinea. Opportunities and Impediments to Private Sector Investment and Development. Study for the Australian Agency for International Development (AusAID). Canberra: Asia 
Pacific School of Economics and Government, the Australian National

University.

Cartwright, Ian. 2004. Fisheries Partnership Agreement (FPA) Negotiating Strategy for Phase II Pacific ACP Negotiations with the EU.

Chapman, Lindsay. 2004. Nearshore Domestic Fisheries Development in Pacific Islands Countries and Territories. In Information Paper for 4th Heads of Fisheries Meeting. Noumea: Secretariat of the Pacific Community.

Emberson-Bain, 'Atu (ed). 1994. Sustainable Development or Malignant Growth?: Perspectives of Pacific Island Women. Suva, Fiji: Marama Publications.

Friends of Kananam. 2005. The Kananam Community Say 'NO' to RD Tuna! [Website] c.2003 [cited 17 November 2005]. Available from http://lorikeet.and.com.au/RD/rdtuna.html.

GDRC. 2006. Governance, a Working Definition [Website]. Global Development Research Centre (GDRC) 2006 [cited 12 April 2006]. Available from http://www.gdrc.org/u-gov/work-def.html.

Gillett Preston and Associates. 2000c. A Review of PNG Fishery Policy. Technical Document No. 4. In Fisheries Development Project ADB Loan No: 1656-PNG. Port Moresby: Papua New Guinea National Fisheries Authority.

Gillett, Robert. 2003. Domestic Tuna Industry Development in the Pacific Islands. The Current Situation and Considerations for Future Development Assistance. In FFA Report 03/01. Honiara: Forum Fisheries Agency.

Gillett, Robert, and Chris Lightfoot. 2002. Contribution of Fisheries to the Economies of Pacific Island Countries, Pacific Studies Series. Manila: Asian Development Bank.

Gomez, B, ed. 2005. PNG's Robust Tuna Industry. In Papua New Guinea Yearbook. Port Moresby: Yong Shan Fook. 
Government of Kiribati. 2003. Kiribati Tuna Development and Management Plan 2003-

2006. Vol. I Executive Summary and the Plan. Bairiki, Tarawa, Kiribati:

Ministry of Natural Resources Development.

Greenpeace. c.2005. Development Without Destruction. Towards Sustainable Pacific

Fisheries (booklet). Suva, Fiji: The Oceans Campaign Greenpeace Australia

Pacific (greenpeace@connect.com.fj).

Hand, Anthony J. 1999. A Review of Fisheries Taxation and Licensing in Solomon Islands. Manila: Asian Development Bank.

Hughes, Anthony, and Odin Thaanum. 1995. Costly Connections: A Performance Appraisal of Solomon Taiyo Limited. Forum Fisheries Agency Report No. 95/54. Honiara: Investment Corporation of Solomon Islands.

Islands Business. 2004. We Say. Islands Business.

Johnson, Isabelle. 1997. Redefining the Concept of Governance. Gatineau, Quebec: Political and Social Policies Division, Policy Branch, Canadian International Development Agency.

Kinch, Jeff, Mark Baine, Augustine Mungkaje, Casper Dako, Teddy Bagi, and Micah Aranka. 2005. Moving Towards Management: An Analysis of the Socioeconomic Conditions and Catch Data of the European Union's Rural Coastal Fisheries Development Programme's Fisher Groups, Madang Province, Papua New Guinea. Port Moresby: Motupure Island Research Centre, University of Papua New Guinea.

Krampe, Paul. 2006. Rising fuel prices and its impact on the tuna industry. Tuna 2006 — 9th Infofish World Tuna Trade Conference, 27 May. Bangkok.

Lewis, Anthony. 2004. A Review of Current Access Arrangements in Pacific Developing Member Countries (PDMCs). ADB Project TA 6128-REG: 
Alternative Negotiating Arrangements to Increase Fisheries Revenues in the Pacific: Asian Development Bank (ADB).

Lewis, Anthony. 2005. Fisheries - A Key Economic Sector at the Crossroads: A Review of Recent Developments in the Fisheries Sector of PNG, its Current Status and Prospects for the Future. Unpublished manuscript prepared for the Institute of National Affairs, Papua New Guinea.

Mani, Luke. 1994. An Assessment of Fish Cannery Effluent Discharge on Pollution Status of the Noro Sea Front, Western Province. Honiara: Solomon Islands College of Higher Education.

Pacific Islands Forum Secretariat. 2004. Forum Leaders' Communique, Thirty-Fifth Pacific Islands Forum, Apia, Samoa, 5-7 August.

Petersen, Elizabeth. 2002. Economic Policy, Institutions, and Fisheries Development in the Pacific. Marine Policy 26:315-324.

- 2002. Institutional Structures of Fishery Management: The Fortuna in the South Pacific. In Resources Management in Asia Pacific Developing Countries, edited by R. Garnaut. Canberra: Asia Pacific Press.

Pitts, Maxine. 2002. Crime, Corruption and Capacity in Papua New Guinea. Canberra: Asia Pacific Press, Australian National University. Post-Courier. 2005. Condom in Tinned Fish Probed. Post-Courier, 31 May, 2.

Reid, Christopher, Michel Bertignac, and John Hampton. 2006. Further development of, and analysis using, the Western and Central Pacific Bioeconomic Tuna Model (WCPBTM). ACIAR project, Maximizing the Economic Benefits to Pacific Islands Nations from Management of Migratory Tuna Stocks, Technical Paper No. 2. http://www.business.latrobe.edu.au/public/staffhp/jkennedy/ACIARTechPapers _files/aciarTP2Further\%20DevelopmentsWCPOBTM.pdf 
Sasabe, Mari. 1993. A Woman's Story: Japan's Economic Involvement in the Pacific.

Suva: Pacific Conference of Churches.

Solomon Star. 2004. Fishermen Monitored for HIV/AIDS. Solomon Star, 12 November. SPC. 2004. Report of the Scientific Committee. Working Paper WCPFC/Comm.2/22.

Noumea, New Caledonia: Secretariat of the Pacific Community (SPC).

— 2005. Tuna Fisheries and their Impacts in the Western and Central Pacific

Ocean. Secretariat of the Pacific Community (SPC) 2005 [cited 21 November 2005]. Available from

http://www.spc.int/artImpact\%20of\%20tuna\%20fisheries.htm.

SPC. 2005. Western and Central Pacific Fisheries Commission Tuna Fishery Yearbook

2004. Oceanic Fisheries Programme (ed. T. Lawson), Secretariat of the Pacific

\section{Community, Noumea, New Caledonia.}

Stinus-Remonde, Marit. 2005. Mission Impossible: A Tremendous Impact. The Manila Times 2004 [cited 18 November 2005]. Available from

http://www.manilatimes.net/national/2004/oct/19/yehey/opinion/20041019opi2. html.

Sullivan, Nancy, Thomas Warr, Joseph Rainbubu, Jennifer Kunoko, Francis Akauna, Moses Angasa, and Yunus Wenda. 2003. Tinpis Maror: A Social Impact Study of Proposed RD Tuna Cannery at Vidar Wharf, Madang. Madang, Papua New Guinea: Nancy Sullivan and Associates.

Tai, Baeau. 2005. High Freight Costs Hurt PNG Tuna Exports [Newspaper article]. The National 2004 [cited 21 October 2005]. Available from www.thenational.com.pg.

The National. 2005. Tuna Cold War. The National, 17 June.

van Santen, Gert, and Philipp Muller. 2000. Working Apart or Together: An Analysis of Selected Benefits and Costs of a Common Approach to Management of the 
Tuna Resources in Exclusive Economic Zones of Pacific Island Countries. Honiara, Solomon Islands: World Bank.

Wallis, Ian. 1999. Noro Fish Processing Facility Waste Water Treatment and Effluent Disposal. Geneva: World Health Organization.

WCPFC. 2005. Report of the First Regular Session of the Scientific Committee of the Commission for the Conservation and Management of Highly Migratory Fish Stocks in the Western and Central Pacific Ocean. Noumea, New Caledonia: Western and Central Pacific Fisheries Commission (WCPFC).

Williams, Peter, and Christopher Reid. 2004. Overview of the Western and Central Pacific Ocean Tuna Fisheries - 2003. In SCTB17 Working Paper GEN-1. Noumea, New Caledonia and Honiara, Solomon Islands: Secretariat of the Pacific Community and Forum Fisheries Agency.

WWF. 2005. Europeans Prefer Responsibly Sourced Seafood [Press release]. World Wild Fund for Nature (WWF) 2005 [cited 14 December 2005]. Available from http://panda.org/news_facts/newsroom/index.cfm?uNewsID=53680. 